\title{
Membuka Peluang Berwirausaha Untuk Pemberdayaan Anak Berkebutuhan Khusus
}

\author{
Ibnu Syamsi \\ FIP, Universitas Negeri Yogyakarta, email: Pastuti2001@yahoo.com
}

\begin{abstract}
Abstrak: Penelitian ini bertujuan unutuk mengembangkan pelatihan kewirausahaan dan materi kewirausahaan dalam rangka pemberdayaan anak berkebutuhan khusus di masyarakat. Metode yang digunakan research and development atau penelitian dan pengembangan, dengan cara pendekatan kualitatif dan kuantitatif. Setelah melakukan serangkain uji coba, kemudian dilakukan uji operasional lapangan yang sebenarnya dengan model pretest and post design. Pengumpulan data menggunakan cara wawancara, observasi partisipatif, diskusi intensif, studi dokumentasi dan angket. Analisis data yang digunakan dengan deskriptif dan uji statistik inferensial dalam hal ini menggunakan uji-tanda. Hasil penelitian yang diperoleh rancangbangun peluang berwirausaha dan bentuk pelatihan yang tepat diterapkan untuk pemberdayaan anak berkebutuhan khusus, materi kerwirausahaan yang cocok diterapkan untuk anak berkebutuhan khusus, efektivitas bentuk pelatihan dan materi kerwirausahaan untuk anak berkebutuhan khusus untuk meningkatkan kemampuannya dalam berwirausaha.
\end{abstract}

Kata kunci: peluang, berwirausaha, pemberdayaan anak berkebutuhan khusus

\begin{abstract}
The purpose of study is to make a device of the development of entrepreneurship training, the develop a model of the entrepreneurship training, and to creat the material of entrepreneurship training for the special need child in community. The study employs research and development as the method and uses qualitative and quantitative as the approaches. After a series of trial is conducted, the real field operational test is performed by using pre-test and post-test design. The data is collected through interviews, participative observations, intensive discussion, documentation study, and questioners. Further, it is analyzed using descriptive analysis and inferential statistics using mark-test. The result of this study embrace the development of proper design of entrepreneurship training device for the children with special need, the development of the model of entrepreneurship training for the special need child, and the development of effective entrepreneurship training material for the applicant of the fresh entrepreneur in the special need child, that can increase one's skill in running a business.
\end{abstract}

Key words: oppotunity, entepreneurship, empowering children with special need

\section{Pendahuluan}

Bila diamati jumlah pengangguran di masyarakat saat ini masih sangat tinggi. Sebagaimana dikatakan Menteri Kuangan Republik Indonesia (Metro TV, 02/01/07), jumlah pengangguran di Indonesia sekitar 10,7 juta jiwa pada tahun 2006, dan diperkirakan pemerintah akan mampu menekan penurunan angka pengangguran itu menjadi 8 juta jiwa. Sedangkan menurut Bank Dunia (Metro TV, 02/01/07), jumlah orang miskin di Indonesia pada tahun 2005 sekitar 35,1 juta jiwa, pada tahun 2006 naik menjadi sekitar 39,01 juta jiwa orang, dan pada tahun 2007 diperkirakan jumlah orang miskin di Indonesia naik lagi menjadi sekitar 100 juta jiwa orang. Angka-angka di atas menunjukkan, bahwa usaha yang dilakukan untuk menurunkan angka pengangguran belum sebanding dengan kenaikan angka pengangguran.

Dalam harian Kompas 24 Juni (2004) dikatakan, bahwa pengangguran akan melanda negeri ini tahun 2009. Ketika itu dari perkiraan jumlah penduduk 228,9 juta orang, sebanyak 168,9 juta jiwa atau 73,7 persen di antaranya merupakan penduduk usia kerja. Dari jumlah ini, 116,5 juta orang atau 69 persen dari penduduk usia kerja dipastikan menyerbu pasar kerja sehingga sangat menakutkan karena pertumbuhan ekonomi belum jelas besarannya. Perkiraan-perkiraan jumlah 
pengangguran yang demikian tinggi ini, berdasarkan angka-angka perhitungan kenaikan angka kelahiran berdasarkan formulasi yang telah ada. Data yang dikemukakan oleh pemerintah, Bank Dunia dan Kompas adalah data yang sangat akurat, angka 69 persen dari jumlah penduduk secara keseluruhan pada tahun 2009 merupakan angka yang bias.

Jumlah pengangguran untuk anak berkebutuhan khusus, bila dilihat secara linier tidak berbeda jauh dengan pengangguran yang ada dalam masyarakat saat ini. Atau lebih parah lagi bila dibandingkan dengan pengangguran pada umumnya, karena sebagian masyarakat masih melihat anak berkebutuhan khusus dengan tutup mata. Pada hal prevalensi anak berkebutuhan khusus yang ada dalam masyarakat diperkirakan $11,50 \%$ versi masyarakat $A S, 1,48 \%$ versi $B P S$, dan 81.438 orang versi Direktorat PLB. Ini berarti, bila pengangguran dalam masyarakat di atas angka $10 \%$, maka jumlah pengangguran untuk anak berkebutuhan khusus di kisaran angkaangka ini. Angka-angka seperti ini bukan suatu permasalahan kecil, akan tetapi suatu pekerjaan yang harus diturunkan atau ditekan dengan berbuat atau diberdayakan.

Pemberdayaan adalah salah satu jawaban untuk para pengangguran dalam masyarakat dan begitu juga dengan pengangguran anak berkebutuhan khusus. Memberdayakan masyarakat adalah upaya untuk meningkatkan harkat dan martabat lapisan masyarakat kita yang dalam kondisi sekarang tidak mampu untuk melepaskan diri dari perangkap kemiskinan dan keterbelakangan. Dengan kata lain memberdayakan adalah memampukan dan memandirikan masyarakat. Suharto (2006) mengatakan, pemberdayaan adalah sebuah proses dan tujuan. Sebagai proses adalah serangkaian kegiatan untuk memperkuat kekuasaan kelompok lemah dalam masyarakat, termasuk individu yang mengalami masalah kemiskinan dan pengangguran. Sebagai tujuan, pemberdayaan menunjuk pada hasil yang ingin dicapai oleh sebuah perubahan sosial, yaitu masyarakat berdaya, memiliki kekuasaan dan mempunyai pengetahuan, kemampuan dalam memenuhi kebutuhan hidup baik yang bersifat fisik, ekonomi, maupun sosial, seperti memiliki kepercayaan diri, mampu menyampaikan aspirasi, mempunyai mata pencaharian, berpartisipasi dalam kegiatan sosial, dan mandiri dalam melaksanakan tugas kehidupannya.

Bentuk pelatihan berwirausaha merupakan salah satu cara untuk pemberdayaan anak berkebutuhan khusus. Penyesuaian bentuk pelatihan dengan anak berkebutuhan khusus merupakan suatu keharusan, karena anak berkebutuhan khusus terdiri dari berbagai macam kebutuhan dan dengan karakterisitik yang berbeda-beda juga. Bentuk pelatihan akan menyesuaikan dengan karakteristik masingmasing anak berkebutuhan khusus ini. Pelatihan sangat tergantung dengan model pelatihan itu sendiri dan sangat tergantung pada persentase (\%) penggunaan keterampilan, pengetahuan, dan sikap. Pelatihan lebih mengutamakan penggunaan keterampilan daripada pengetahuan, karena pelatihan lebih mengutamakan bentuk aplikasi. Sebagaimana dikatakan oleh Nadler (Sugiyono, 2003), training is those activities which designed to improve human performance on the job the employee is presently doing or is being hired to do. Latihan (training) adalah semua kegiatan yang dirancang untuk meningkatkan kinerja pegawai pada pekerjaan yang sedang atau akan segera dihadapi.

Diperlukan pengemasan materi kewirausahaan yang cocok dengan karakteristik anak berkebutuhan khusus. Tidak semua materi kewirausahaan dapat diaplikasikan untuk anak berkebutuhan khusus. Karena itu, materi kewirausahaan harus dikemas sebaik mungkin dan disesuaikan dengan masing-masing karakteristik anak berkebutuhan khusus. Materi kewirausahaan sedikit abstrak dan sulit, sehingga tidak semua orang dapat mencernak dan memahaminya dengan cepat. Hanya sebagian kecil masyarakat yang dapat memahaminya dan berbakat serta mempunyai potensi unggul dalam berwirausaha. Yang sedikit itu, juga terdapat dalam lingkungan anak berkebutuhan khusus. Oleh karena itu, diperlukan kepiawaian untuk membuka peluang berwirausaha untuk anak berkebutuhan khusus ini.

Efektivitas bentuk pelatihan dan materi berwirausaha untuk anak berkebutuhan khusus sangat didambakan, dalam rangka menggali potensi kewirausahaan untuk anak berkebutuhan 
khusus. Bentuk pelatihan dan materi kewirausahaan yang cocok, sangat diperlukan untuk meningkatkan efektivitas kepelatihan yang akan digunakan dalam melatih berwirausaha anak berkebutuhan khusus. Ini adalah salah satu cara untuk memberdayakan anak berkebutuhan khusus dengan membuka peluang berwirausaha bagi mereka.

Dengan dasar latar belakang di atas, dapat dirumuskan masalahnya sebagai berikut: Bagaimana membuka peluang berwirausaha untuk memberdayaan anak berkebutuhan khusus ? berdasarkan rumusan masalah ini, pertanyaanpertanyaan dapat dikembangkan dan disusun menjadi beberapa sub-rumusan masalah atau pertanyaan yang lebih spesifik dan rinci, yang meliputi: 1) Bagaimana bentuk rancangbangun peluang berwirausaha untuk pemberdayaan anak berkebutuhan khusus? 2) Bagaimana bentuk pelatihan berwirausaha yang tepat diterapkan untuk anak berkebutuhan khusus? 3) Bagaimana materi berwirausaha yang cocok diterapkan untuk anak berkebutuhan khusus? 4) Apakah dengan bentuk pelatihan dan materi berwirausaha untuk anak berkebutuhan khusus efektif untuk meningkatkan kemampuannya dalam berwirausaha?

Penelitian ini bertujuan untuk mengembangkan pelatihan kewirausahaan dan materi kewirausahaan dalam rangka pemberdayaan anak berkebutuhan khusus di masyarakat.

\section{Kajian Literatur}

\section{Anak Berkebutuhan Khusus}

Konsep sederhana mengenai anak berkebutuhan khusus dapat dirumuskan sebagai berikut: pengertian anak berkebutuhan khusus, karakteristik, identifikasi, prevalensi, jenis anak berkebutuhan khusus (yang terdiri dari, kelainan mental, berkesulitan belajar spesifik, kelainan fisik, tunanetra, tunarungu, kelainan wicara, kelainan emosi, gifted, talented, lambat belajar, autis, korban narkoba, indigo), faktor penyebab, dampak terjadinya, hak yang dimiliki anak berkebutuhan khusus, layanan pendidikan, konsep layanan, model layanan, dan pendidikan inklusi.

Anak berkebutuhan khusus (Direktorat PLB, 2008) adalah anak yang secara signifikan (bermakna) mengalami kelainan atau penyimpangan fisik, pertumbuhan atau perkembangannya dibandingkan dengan anak-anak lain seusianya sehingga mereka memerlukan pelayanan pendidikan khusus. Karakteristik anak berkebutuhan khusus (Suparno, 2008), yaitu kelainan fisik, kelainan mental identifikasi anak berkebutuhan khusus dan emosi, kelainan akademik. Identifikasi anak berkebutuhan khusus (Suparno, 2008) adalah suatu usaha seseorang (orang tua, guru, maupun tenaga kependidikan lainnya) untuk mengetahui apakah seorang anak mengalami kelainan atau peyimpangan (phisik, intelektual, sosial, emosional/tingkah laku) dalam pertumbuhan atau perkembangannya dibandingkan dengan anak-anak lain seusianya (anak-anak normal). Anak berkebutuhan khusus adalah anak yang seharusnya mendapatkan pelayanan secara wajar sesuai dengan kebutuhannya, karena secara intelektual anak berkebutuhan khusus mempunyai perkembangan yang bervariasi seperti juga anak-anak pada umumnya (kecuali anak tunagrahita).

Dalam rangka membuka peluang berwirausaha anak berkebutuhan khusus, yang penting bagi kita adalah makna konsep anak berkebutuhan khusus itu sendiri. Konsep ini sangat penting bagi kita untuk mengkaitkannya dengan pemberdayaan berwirausaha. Pelatihan adalah cara yang dipilih dalam pemberdayaan anak berkebutuhan ini. Oleh karena itu, pemberdayaan berwirausaha yang bagaimana yang tepat di implimentasikan pada anak berkebutuhan ini.

\section{Pemberdayaan}

Secara konseptual, pemberdayaan atau pemberkuasaan (empowerment) berasal dari kata 'power' (kekuasaan). Karenanya, ide utama pemberdayaan bersentuhan dengan konsep mengenai kekuasaan. Kekuasaan seringkali dikaitkan dengan kemampuan kita untuk membuat orang lain melakukan apa yang kita inginkan, terlepas dari keinginan dan minat mereka. Ilmu sosial tradisional menekankan kekuasaan berkaitan dengan pengaruh dan kontrol. Pengertian ini mengasumsikan kekuasaan sebagai sesuatu yang tidak berubah atau tidak dapat dirubah. Suharto (2006) mengatakan, pemberdayaan adalah sebuah proses dan tujuan. Sebagai proses adalah 
serangkaian kegiatan untuk memperkuat kekuasaan kelompok lemah dalam masyarakat, termasuk individu yang mengalami masalah kemiskinan dan pengangguran. Sebagai tujuan, pemberdayaan menunjuk pada hasil yang ingin dicapai oleh sebuah perubahan sosial, yaitu masyarakat berdaya, memiliki kekuasaan dan mempunyai pengetahuan, kemampuan dalam memenuhi kebutuhan hidup baik yang bersifat fisik, ekonomi, maupun sosial, seperti memiliki kepercayaan diri, mampu menyampaikan aspirasi, mempunyai mata pencaharian, berpartisipasi dalam kegiatan sosial, mandiri dalam melaksanakan tugas kehidupannya.

Dalam penelitian ini yang dikatakan pemberdayaan adalah serangkaian kegiatan untuk meningkatkan aset dan kemampuan agar mau dan mampu mengakses berbagai sumber daya, permodalan, teknologi dan pasar dengan pendekatan pendampingan, peningkatan kapasitas, pelayanan dan pembelaan menuju kemandirian anak berkebutuhan khusus. Dari pandangan-pandangan di atas yang dimaksud dengan pemberdayaan anak berkebutuhan khusus dalam penelitian ini adalah sejumlah orang yang membutuhkan apa yang dibutuhkannya, maka mereka perlu mendapatkan kegiatan untuk meningkatkan aset dan kemampuan agar mau dan mampu mengakses berbagai sumber daya, permodalan, teknologi dan pasar dengan pendekatan pendampingan, peningkatan kapasitas, pelayanan dan pembelaan menuju kemandirian anak berkebutuhan khusus.

Dalam penelitian ini, pemberdayaan yang digunakan adalah pelatihan, ada beberapa pokok permasalahan yang terkait, yaitu pengantar pelatihan, asesmen kebutuhan dan rancangbangun pelatihan, proses pelatihan, dan pascapelatihan.

Untuk mengembangkan pelatihan anak berkebutuhan khusus, berawal dengan pengertian pelatihan adalah proses mengajarkan anak berkebutuhan khusus, keterampilan dasar yang mereka butuhkan untuk menjalankan usahanya. Dalam asesmen kebutuhan dan rancangbangun pelatihan banyak mempelajari mengenai, analisis kebutuhan, rancangan pelatihan yang efektif, rencana pemenuhan kebutuhan, pengelolaan anggaran pelatihan, metode pembelajaran, seleksi instruktur pelatihan, menyiapkan materi dan menulis materi pelatihan. Proses pelatihan (Davies, 2005) menurutnya adalah menyampaikan materi pelatihan, artinya mengidentifikasi perilaku yang menunjang penyampaian materi pelatihan secara efektif, menetapkan perilaku yang dibutuhkan untuk menyampaikan materi seara efektif, menyampaikan dan menyiapkan materi pelatihan dengan tetap menjaga minat peserta. Untuk pascapelatihan, banyak mengkaji mengenai kelanjutan dari pengembangan pelatihan dan pembicaraan difokuskan pada meningkatkan keterampilan pelatihan, pelatihan dalam masyarakat, mengevaluasi efektivitas pelatihan dan pengembangan profesional berkelanjutan.

\section{Berwirausaha}

Untuk pengembangan kewirausahaan, konsep sederhananya adalah pengertian berwirausaha, karakteristik wirausaha, perencanaan keuangan, penggunaan sumber daya, dan spesifikasi usaha. Yang dimaksud berwirausaha dalam tulisan ini adalah kemampuan anak berkebutuhan khusus untuk membuat sesuatu yang baru dan berbeda (kreativitas dan inovasi) dalam membuka lapangan usaha baru dan mampu mengorganisasi, menanggung resiko, berorientasi hasil, peluang, kepuasan pribadi, kebebasan, mental dan sikap jiwa yang selalu aktif berusaha meningkatkan hasil karya dalam arti meningkatkan penghasilan. Karakteristik wirausaha adalah kepribadian yang dimiliki pengusaha, seperti jiwa wirausaha, kepemimpinan, mengambil resiko, mengambil keputusan, perencanaan bisnis, menggunakan waktu secara efektif. Suryana (2006) mengatakan, kewirausahaan merupakan suatu kemampuan dalam menciptakan nilai tambah di pasar melalui proses pengelolaan sumber daya dengan cara baru dan berbeda-beda, seperti pengembangan teknologi, penemuan pengetahuan, perbaikan produk barang dan jasa, menemukan cara baru untuk mendapatkan produk lebih banyak dengan sumber daya lebih efisien.

Perencanaan keuangan adalah kemampuan mengendalikan uang, seperti rencana tindakan keuangan, mengembangkan sikap perhitungan keuangan terhadap sumber daya, mengukur dan mengendalikan strategi hasil keuangan, sukses keuangan melalui orang, perangkat untuk 
pengendalian keputusan (sistem informasi). Dan penggunaan sumber daya adalah penempatan sumber daya yang sesuai, seperti memperoleh sumberdaya langka, menilai peluang pasar, memasarkan barang atau jasa, menggunakan sumberdaya luar, dan berhubungan dengan badan pemerintah.

Tujuan kewirausahaan menurut Kasmir (2006) adalah persahabatan dan pergaulan, menyenangkan orang lain, membujuk pelanggan, mempertahankan pelanggan, membina dan menjaga hubungan. Dalam penelitian ini yang dimaksud tujuan kewirausahaan adalah kemampuan anak berkebutuhan khusus memberdayakan semangat, sikap, perilaku dapat mengaplikasikan pengetahuan, manajemen, dan kreativitas untuk mengembangkan bidang usaha (individu atau kelompok), persahabatan dan pergaulan, menyenangkan orang, membujuk dan mempertahankan pelanggan, membina dan menjaga hubungan, keberanian, keutamaan, keperkasaan untuk memenuhi kebutuhan dan memecahkan permasalahan hidup.

Kuswara (2005) mengatakan, sasaran kewirausahaan adalah 1) generasi muda, peserta pendidikan nonformal, anak putus sekolah, calon wirausaha, 2) pelaku ekonomi yang terdiri dari atas pengusaha mikro (kecil), menengah dan koperasi, 3) instansi pemerintah yang melakukan kegiatan kemitraan dengan usaha kecil, menengah dan koperasi untuk organisasi profesi dan kelompok masyarakat.

Manfaat kewirausahaan menurut Kuswara (2005) adalah: 1) usaha memberi bantuan pada orang lain sesuai dengan kemampuan; 2) menambah daya tampung tenagakerja dan mengurangi pengangguran; 3 ) memberi contoh bekerja keras, tekun, tetapi tidak melupakan perintah agama; 4) menjadi contoh bagi masyarakat sebagai pribadi unggul yang patut diteladani; 5) sebagai generator pembangunan lingkungan, pribadi, distribusi, pemelihara lingkungan, kesejahteraan, 6) berusaha mendidik karyawan menjadi orang mandiri, disiplin, tekun, jujur dalam menghadapi pekerjaan dan; 7) berusaha mendidik masyarakat hidup efisien, ekonomis, tidak berfoya-foya dan tidak boros.

Fungsi dan peran wirausaha dikatakan oleh Suryana (2006), dapat dilihat dari dua pen- dekatan, yaitu secara mikro dan makro. Secara mikro wirausaha memiliki dua peran, yaitu penemu (innovator) dan perencana (planner). Sebagai penemu wirausaha menemukan, menciptakan sesuatu yang baru seperti produk, teknologi, cara, ide, organisasi dan sebagainya. Sebagai perencana wirausaha berperan merancang tindakan dan usaha baru, merencanakan strategi usaha baru, ide dan peluang meraih sukses, membuat organisasi perusahaan baru dan lainlain. Secara makro peran wirausaha menciptakan kemakmuran, pemerataan kekayaan, kesempatan kerja berfungsi sebagai mesin pertumbuhan ekonomi suatu negara.

Karakteristik kepribadian wirausaha membicarakan mengenai berjiwa wirausaha, kepemimpinan, mengambil risiko, mengambil keputusan, perencanaan bisnis, menggunakan waktu secara efektif. Perencanaan dan pengendalian keuangan membahas mengenai perencanaan tindakan keuangan, mengembangkan sikap perhitungan keuangan terhadap sumberdaya, mengukur dan mengendalikan strategis serta hasil keuangan, sukses dibidang keuangan melalui orang, perangkat untuk pengendalian keputusan (sitem informasi). Penggunaan sumberdaya membahas mengenai memperoleh sumberdaya langka, menilai peluang pasar, memasarkan barang atau jasa, menggunakan sumberdaya luar, berhubungan dengan badan pemerintah.

\section{Metode Penelitian}

Konsep penelitian dan pengembangan dari Borg and Gall (Sukmadinata, 2006) ada 10 tahap. Kesatu, penelitian dan pengumpulan informasi (research and information collecting) teori, hasil studi dan informasi yang relevan dengan masalah penelitian yang mencakup asesmen kebutuhan, kajian pustaka, studi penelitian berskala kecil, penyiapan laporan, pertimbangan nilai yang berlaku di lokasi penelitian. Kedua, perencanaan (planning), pada tahap ini mencakup pendefinisian keterampilan yang dipelajari, merumuskan dan mengurutkan tujuan, mengidentifikasi kegiatan belajar, dan uji validasi berskala kecil. Ketiga, mengembangkan produk awal (develop preliminary form of product) mencakup penyiapan rancangbangun pelatihan, materi kewirausahaan untuk 
anak berkebutuhan khusus, prosedur, instrumen evaluasi pengembangan dan efektivitas pelatihan kewirausahaan. Kemudian diperoleh bentuk pelatihan, dan materi kewirausahaan untuk anak berkebutuhan khusus secara hipotetik. Keempat, uji coba lapangan produk awal (preliminary field testing), uji coba terbatas dilakukan di beberapa tempat menggunakan sejumlah subjek. Data interviu, observasi dan angket dikumpulkan dan dianalisis. Kelima, revisi produk utama (main product revision), merevisi produk yang disarankan hasil uji coba lapangan produk awal. Keenam, uji lapangan utama (main field testing) atau uji coba diperluas, dilakukan di beberapa tempat dengan sejumlah peserta pelatihan. Data kuantitatif tentang kinerja peserta pelatihan berkenaan dengan penampilan peserta pelatihan kewirausahaan sebelum mendapat perlakuan dan setelah mendapat perlakuan, dikumpulkan dan dianalisis. Serta hasil-hasil dievaluasi berkenaan dengan tujuan yang ingin dicapai. Ketujuh, penyempurnaan revisi produk operasional (operational product revision), revisi produk sebagaimana disarankan oleh hasil uji lapangan utama. Kedelapan, uji lapangan operasional (operational field testing), uji validasi bentuk pelatihan dan materi kewirausahaan dilakukan di beberapa tempat pada peserta pelatihan kewirausahaan. Data dikumpulkan melalui interviu, observasi dan angket selanjutnya dianalisis. Kesembilan, revisi produk final (final product revision), merevisi produk terakhir sebagaimana disarankan hasil uji lapangan operasional. Kesepuluh, diseminasi dan implementasi (dissemination and implementation), melaporkan produk yang disampaikan melalui pertemuan profesional dan jurnal. Bekerja sama dengan penerbit untuk didistribusikan secara komersial. Melakukan monitoring terhadap distribusi untuk mengendalikan kualitas.

\section{Populasi dan Sampling}

Populasi penelitian adalah seluruh data yang ada di wilayah penelitian (Jakarta Barat) yang berhubungan dengan masalah penelitian. Dalam pengertian ini data adalah seluruh hasil yang didapat dari pengambilan dokumentasi, observasi, wawancara, angket terhadap pejabat dan orang yang terkait dengan masalah penelitian, hasil angket terhadap membuka peluang berwirausaha anak berkebutuhan khusus di lokasi penelitian. Menurut Zuriah (2006) populasi adalah seluruh data yang menjadi perhatian penelitian dalam suatu ruang lingkup dan waktu yang ditentukan. Jadi, populasi berhubungan dengan data, bukan faktor manusianya. Kalau setiap manusia memberikan suatu data, maka ukuran populasi sama dengan banyaknya manusia. Kemudian McMillan and Schumacher (2001) mengatakan, populasi adalah sekelompok elemen baik individual, objek, peristiwa yang berhubungan dengan kriteria spesifik dan merupakan sesuatu yang menjadi target generalisasi hasil penelitian.

Yang dimaksud sampel dalam penelitian adalah sebagian data yang diambil dari populasi secara keseluruhan, berarti sampel penelitian sebagian dari data peluang berwirausaha, pemberdayaan dan anak berkebutuhan di lokasi penelitian (sebagian anak berkebutuhan khusus yang ada di wilayah Jakarta Barat) yang didapat dari hasil studi dokumentasi, observasi, wawancara, angket terhadap pejabat, pelaksanaan berwirausaha terhadap anak berkebutuhan khusus yang ada di lokasi penelitian. Istijanto (2005) mengatakan, populasi diartikan sebagai jumlah keseluruhan semua anggota yang diteliti, sedangkan sampel merupakan bagian yang diambil dari populasi. McMillan and Schumacher (2001) mengatakan, sampel adalah sekelompok subjek yang menghasilkan data yang diambil (walaupun subjek tersebut tidak diambil dari populasi).

\section{Teknik Pengumpulan dan Analisis Data}

Ada empat tahap analisis data yang harus dilalui, yaitu pendahuluan, pemberdayaan, ujicoba pemberdayaan berwirausaha, pelaksanaan pemberdayaan berwirausaha secara operasional. Tahap pendahuluan dilakukan kajian mengenai temuan fakta-fakta tentang membuka peluang berwirausaha anak berkebutuhan di lapangan, melakukan kajian interpretasi secara kualitatif terhadap temuan-temuan lapangan. Tahap pemberdayaan peluang bewirausaha anak berkebutuhan, dilakukan beberapa analisis pendekatan, yaitu menyusun disain rancangbangun berwirausaha, materi berwirausaha untuk 
pemberdayaan, efektifitas pemberdayaan dengan berwirausaha, mendeskripsikan dan menyajikan data, menganalisis secara kualitatif, ujicoba secara bertahap, hasil ujicoba peluang berwirausaha dan angket dianalisis dengan memakai pendekatan kuantitatif dan analisis deskriptif kualitatif. Analisis statistik dengan uji-tanda digunakan untuk mengukur peluang bewirausaha sebelum dan sesudah dilaksanakan pemberdayaan.

Tahap ujicoba dan implementasi pemberdayaan berwirausaha, hasil pemberdayaan berwirausaha dianalisis dengan pendekatan kuantitatif, dengan menggunakan hasil kelompok pembelajaran (eksperimen) sebelum dan sesudah dilaksanakan. Data yang sudah diperoleh dimaknai melalui penganalisisan data. Uji coba pemberdayaan berwirausaha dilakukan beberapa kali sesuai dengan kebutuhan yang diharapkan.

Tahap pelaksanaan pemberdayaan berwirausaha secara operasional dilapngan atau uji validasi, dilakukan dalam kelompok yang lebih besar. Hasil evaluasi pemberdayaan dianalisis dengan menggunakan uji statistik (kuantitatif) dari data angket sebelum dan sesudah pembelajaran. Kemudian data yang diperoleh dimaknai sesuai dengan jenis masing-masing data.

Faisal (Bungin, 2003) mengatakan, dalam penelitian kualitatif 'tabel' dianggap tercantum dalam kenyataan sehari-hari di masyarakat, bukan tercantum di atas kertas. Data yang terkumpul secara kualitatif, seperti catatan lapangan, komentar peneliti, gambar, foto, dokumen, biografi, artikel serta data lainnya akan dikatagorisasikan, dikelompokan, diurutkan, diberi kode dan dimaknai atau ditafsirkan secara kualitatif. Data dikelola dan diorganisasi sesuai dengan tujuan penelitian untuk menemukan subtema dalam rangka menjawab hipotesis dan diangkat menjadi teori.

Penelitian ini menggunakan analisis data yang dikemukakan Faisal (Bungin, 2003), yaitu mengumpulkan data, mereduksi data (data reduction), display data, dan conclution drawing and verification.

\section{Waktu dan Tempat Penelitian}

Penelitian dengan judul membuka peluang berwirausaha untuk pemberdayaan anak berkebutuhan khusus (suatu diskripsi analisis tentang pemberdayan anak berkebutuhan khusus) dilaksanakan di wilayah kotamadya Jakarta Barat, dengan jurasi waktu penelitian selama tiga bulan dan hasilnya harus dilaporkan. Sedangkan untuk melakukan ujicoba operasional, di balai latihan kerja daerah Jakarta Barat.

\section{Hasil Penelitian dan Bahasan Pemberdayaan Anak Berkebutuhan Khusus}

Pengembangan bentuk pelatihan untuk anak berkebutuhan khusus yang diselenggarakan ini disesuaikan dengan karakteristik anak berkebutuhan khusus. Kelompok ini mempunyai gaya hidup dengan karakteristik yang spesifik. Pengembangan pelatihan untuk anak berkebutuhan khusus adalah upaya-upaya yang harus dibuat dan digali untuk menemukan bentuk pelatihan yang sesuai dengan karakteristik kelompok anak berkebutuhan khusus ini. Pengembangan bentuk pelatihan ini diharapkan sesuai dengan karakteristik hidup anak berkebutuhan khusus dan mereka dapat dilatih secara cepat dan berkualitas sesuai dengan standarisasi profesional dalam skala standarisasi lokal, nasional dan internasional. Perkembangannya dengan cara melakukan bentuk pelatihan secara berkesinambungan, mempercepat dan meningkatkan usahanya secara profesional dan juga dengan kerwirausahaan yang selalu berkembang secara terus menerus.

Bentuk pengembangan pelatihan untuk anak berkebutuhan khusus menjadi calon pengusaha baru adalah bentuk pelatihan kewirausahaan yang sangat fleksibel dan praktis, biaya pelaksanaannya sangat ekonomis, pelaksanaannya sangat fleksibel, proses pelaksanaannya sangat cepat, dapat dilaksanakan oleh siapa saja dan di mana saja, mencerminkan suatu bentuk dasar pelatihan kewirausahaan yang sangat kokoh dan menjangkau jauh ke depan. Pembuatan bentuk pelatihan anak berkebutuhan khusus didasarkan pada profesionalisme akademik yang sesuai dengan gaya hidup anak berkebutuhan khusus, sehingga bentuk pelatihan ini tidak merepotkan penyelenggara dan peserta pelatihan. Bentuk pemberdayaan anak berkebutuhan khusus disajikan pada Bagan 1. 


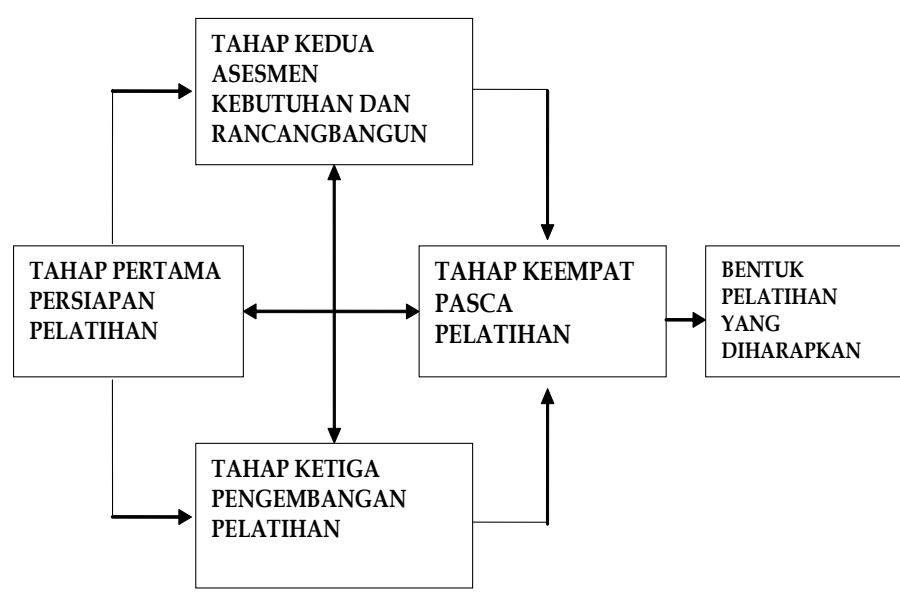

Bagan 1. Bentuk pemberdayaan anak berkebutuhan khusus

\section{Materi Pemberdayaan Dengan Kewirausahaan Anak Berkebutuhan Khusus}

Pengembangan materi kewirausahaan untuk anak berkebutuhan khusus yang digunakan dalam proses pembelajaran, disesuaikan dengan kemampuan dan potensi anak berkebutuhan khusus. Materi yang ada dalam pelatihan kewirausahaan harus disesuaikan dengan bentuk pelatihan kewirausahaan kelompok anak berkebutuhan khusus di atas dan karakteristik kehidupan anak berkebutuhan khusus yang ada dalam masyarakat. Pengembangan materi kewirausahaan untuk anak berkebutuhan khusus yang dibuat berupaya untuk menggali dan menemukan materi kewirausahaan untuk kelompok anak berkebutuhan khusus yang dapat melahirkan calon-calon pengusaha baru yang profesional dan berkualitas.

Materi kewirausahaan untuk anak berkebutuhan khusus ini dibuat secara integratif, komprehensif dan sinkronisasi. Integratif berarti pembuatan materi pelatihan kewirausahaan untuk anak berkebutuhan khusus saling berkorelasi antara komponen-komponen yang ada dalam sesi materi pelatiahan kewirausahaan. Komprehensif berarti materi kewirausahaan, kedalaman isinya disesuaikan dengan potensi anak berkebutuhan khsusus tersebut. Sinkronisasi berarti bahwa materi kewirausahaan anak berkebutuhan khusus cocok dan sesuai dengan kelompok anak ini.

Kelebihan pengembangan materi kewirausahaan untuk anak berkebutuhan khusus adalah materi kewirausahaan yang mudah dicerna, bahasa yang digunakan sederhana dan tidak terlalu berbelit-belit. Materi kewirausahaan yang dibuat untuk anak berkebutuhan khusus ini telah diujicobakan pada kelompok-kelompok yang karakteristiknya sangat homogen. Ada karakteristik spesifikasi dari konsep materi kewirausahaan untuk anak berkebutuhan khusus yang sedang dikembangkan ini, yaitu dari segi bahasa yang digunakan, konsep-konsep yang digunakan, rancangbangun yang dibuat dan evaluasi akhir pembelajaran. Pemilahan bahasa, konsep dan evaluasi akhir pembelajaran untuk pengembangan materi kewirausahaan anak berkebutuhan khusus yang sangat spesifik dan ini terlihat melalui ujicoba-ujicoba yang telah dilakukan.

Selanjutnya, materi kewirausahaan yang dirancang untuk anak berkebutuhan khusus yang ada dalam masyarakat, juga disesuaikan dengan karakteristik yang dimiliki oleh anak berkebutuhan khusus tersebut. Peneliti dalam hal ini setelah merancang, kemudian mendiskusikan materi kewirausahaan ini dengan tim fungsional yang ada di masyarakat, dan para pakar profesional, serta para pejabat pelatihan yang ada di instansi yang bersangkutan dan setelah mereka mengatakan setuju, maka disahkan materi kewirausahaan yang dikembangkan ini. Materi pemberdayaan dengan kewirausahaan anak berkebutuhan khusus disajikan pada Bagan 2.

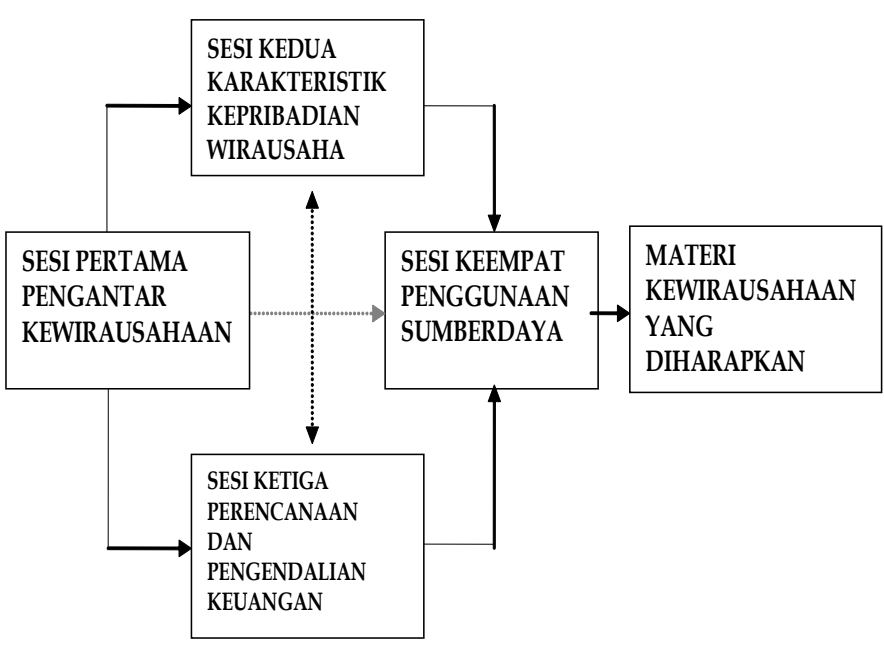

Bagan 2. Materi pemberdayaan dengan kewirausahaan anak berkebutuhan khusus 
Ada beberapa keistimewaan pengembangan materi kewirausahaan untuk kelompok anak berkebutuhan khusus yang dapat ditonjolkan dalam penelitian ini, yaitu menghidupkan perekonomian rakyat, menciptakan lapangan kerja, menurunkan angka pengangguran, melahirkan calon-calon pengusaha baru, dapat mensejahterakan rakyat, menaikkan pendapatan rakyat, menambah banyak uang yang bereder, mengurangi tingkat kejahatan, meningkatkan pendapatan asli daerah, menarik atau membawa uang dari luar ke dalam masyarakat, menaikkan pamor masyarakat khusus anak berkebutuhan khusus sebagai masyarakat yang selalu dipinggirkan.

Pemerintah selama ini belum dapat menekan angka pengangguran secara berarti khususnya anak berkebutuhan khusus, sehingga perlu dicarikan solusi yang dapat menurunkan angka pengangguran anak berkebutuhan khusus secara bertahap. Pelatihan yang diberikan untuk anak berkebutuhan khusus adalah salah satu solusi yang dapat mengatasi permasalahan pengangguran anak berkebutuhan khusus secara berkelanjutan. Pelatihan kewirausahaan untuk anak berkebutuhan khusus ini juga akan melahirkan calon-calon pengusaha baru sehingga dapat meningkatkan kesejahteraan dan perekonomian rakyat.

Yang dimaksud dengan calon pengusaha baru adalah kelompok anak berkebutuhan khusus yang telah diproses melalui pelatihan kewirausahaan, di mana mereka telah mendapatkan pengetahuan, keterampilan dan sikap kewirausahaan dengan bentuk pelatihan yang spesifik dan menggunakan materi pelatihan kewirausahaan yang sesuai dengan kespesifikannya. Mereka dilatih bagaimana cara berwirausaha yang benar guna mengangkat taraf kesejahteraan hidupnya dan bagaimana mengembangkan kemampuan yang ada dalam dirinya untuk berwirausaha semaksimal mungkin. Bagaimana menggunakan peluang yang diberikan oleh pemerintah untuk berwirausaha dalam masyarakat.

Berwirausaha melakukan usaha-usaha dalam rangka memenuhi kebutuhan masyarakat banyak. Proses berwirausaha adalah aktivitas yang saling menguntungkan antara pengusaha dengan konsumen yang membutuhkannya. Berwirausaha adalah proses mengubah produk menjadi rupiah yang akan dikembangkan jumlahnya menjadi lebih banyak lagi, sehingga kebutuhan-kebutuhan masyarakat banyak yang dapat terpenuhi dengan mudah dan harganya terjangkau oleh konsumen.

Berwirausaha secara tradisional melakukan usaha-usaha dengan tidak menggunakan pengetahuan kewirausahaan secara profesional dan modern. Usaha-usaha yang dilakukan secara tradisional sangat lambat berkembang dan terkesan berjalan di tempat dan cara-cara tradisional ini tidak akan pernah membuat usaha menjadi berkembang. Paradigma berwirausaha secara tradisional harus diubah menjadi berwirausaha secara modern dan profesional, agar supaya usaha-usaha yang sedang dijalankannya berkembang secara lebih cepat dan menguntungkan.

Berwirausaha secara profesional adalah aktivitas yang dilakukan secara terencana, terprogram dan dipikirkan secara matang serta berkelanjutan dalam jangka waktu yang panjang. Berwirausaha seperti ini, mempunyai perkembangan-perkembangan yang pasti, karena memang sudah dipersiapkan secara matang dalam jangka waktu yang sudah direncanakan. Dalam penelitian ini dirancang bentuk konseptual penyelenggaran pelatihan kewirausahaan untuk kelompok anak berkebutuhan khusus yang cocok untuk calon pengusaha baru.

Setelah melihat dan mempelajari kedua bagan di atas maka dapat dilihat dengan jelas konsep pengembangan bentuk pelatihan dan materi pelatihan kewirausahaan untuk kelompok anak berkebutuhun khusus. Konsep pengembangan pelatihan kewirausahaan memperjelas bentuk pelatihan yang paling tepat dan cocok dikembangkan untuk kelompok anak berkebutuhan khusus ini. Untuk itu, dicarikan bentuk pelatihan yang sangat sederhana, mudah dilaksanakan dan ringan biayanya serta cepat prosesnya.

Saat ini, masing-masing komponen berada dalam jalur yang kurang berimbang, perlu suatu pemikiran untuk mensinergikan kedua komponen tersebut, sehingga ada kesesuaian. Materi kewirausahaan untuk kelompok anak berkebutuhan khusus mudah diterima peserta pelatihan dan bentuk penyelenggaraan pelatihan 
kewirausahaan cocok dengan kondisi kelompok anak berkebutuhan khusus. Dengan demikian, perlu dicarikan kesesuaian-kesesuaian di antara kedua komponen tersebut, sehingga mudah dilaksanakan untuk kelompok anak berkebutuhan khusus.

Sebagaimana dikatakan para ahli, materi mempunyai ciri-ciri sebagai berikut, yaitu mempunyai kalimat yang mampu menjelaskan sendiri, uraiannya jelas tidak perlu adanya penjelasan tambahan, dapat dipelajari oleh peserta sesuai kecepatan belajar masing-masing peserta, di dalam bahan tersebut ada petunjuk kapan peserta boleh melanjutkan ke bagian berikutnya dan kapan harus mengulang bahan yang sama, dapat dipelajari oleh peserta menurut waktu dan tempat yang dipilihnya, mampu membuat peserta aktif melakukan sesuatu pada saat belajar baik latihan maupun kegiatan praktik.

Perlu dicermati dan dipelajari untuk mengantisipasi perubahan-perubahan dalam jangka pendek, menengah dan panjang dalam rangka perkembangan pelatihan kewirausahaan untuk anak berkebutuhan khusus dalam masyarakat. Perkembangan dunia usaha dalam skala kedaerahan pasar lepas sangat cepat dan saling berpacu untuk mengembangkan usaha-usaha mereka dalam rangka mencari keuntungankeuntungan yang diharapkan.

Keuntungan pengembangan pelatihan kewirausahaan, terutama untuk kelompok anak berkebutuhan khusus dalam masyarakat adalah dalam rangka melahirkan calon-calon pengusaha baru yang lebih banyak lagi, untuk meningkatkan kualitas kewirausahaan yang sudah berjalan akan tetapi masih berjalan di tempat. Secara profesional, calon pengusaha baru yang telah mengembangkan kewirausahaan maka aktivitas kewirausahaan akan mempercepat pemutaran rupiah untuk meningkatkan ekonomi kerakyatan.

Hal yang paling penting peserta pelatihan kewirausahaan kelompok anak berkebutuhan khusus dilatih untuk pandai berwirausaha, untuk itu diperlukan calon pengusaha baru dalam jumlah yang cukup banyak dengan kualitas lokal, nasional dan internasional. Persaingan bebas di pasar lepas memerlukan sumber daya pengusaha yang sangat profesional untuk berwirausaha secara lebih profesional dalam pasar lepas.
Kebanyakan kasus berwirausaha yang ada dalam masyarakat akibat mereka belum mempunyai pengetahuan berwirausaha secara profesional. Akibatnya, mereka selalu dalam keadaan yang tidak sehat dan bahkan ada kecenderungan untuk gagal atau bangkrut dalam menjalankan usahanya. Ketidaktahuan mereka untuk menempuh jalan mana yang harus dilalui dalam menjalankan usaha-usaha yang akan digeluti.

Berwirausaha secara profesional dan modern memerlukan potensi kewirausahaan yang perlu dikembangkan. Dalam rangka pengembangan itu, kualitas pendidikan dan pelatihan kewirausahaan untuk kelompok anak berkebutuhan khusus perlu mendapat perhatian khusus. Menggali potensi pelatihan kewirausahaan untuk kelompok anak berkebutuhan khusus yang ada dalam masyarakat, sebaiknya dikembangkan pusat kajian kewirausahaan untuk kelompok anak berkebutuhan khusus yang dapat bekerja secara terus menerus untuk mempelajari kewirausahaan secara lebih berkualitas.

Bentuk konseptual pengembangan pelatihan dan materi kewirausahaan ini sangat menguntungkan bagi anak berkebutuhan khusus, untuk memulai pekerjaaannya terutama dalam meniti karirnya untuk berwirausaha. Dengan materi pelatihan kewirausahaan ini, kelompok calon pengusaha baru dapat mempelajarinya di mana pun ia berada, karena materi latihan kewirausahaan kelompok anak berkebutuhan khusus ini dapat dipelajari dan didalami secara mandiri di mana pun ia berada, tanpa ada pelatih dengan pengembangan materi yang masih sangat sederhana tetapi berkualitas, terutama anak berkebutuhan khusus yang potensinya unggul.

Sumber daya manusia kelompok calon pengusaha baru dalam masyarakat, sebaiknya mendapat perhatian utama terutama dalam mengubah paradigma kewirausahaan, mengubah pola pikir kewirausahaan, mau melakukan wirausaha secara proaktif, mau melakukan wirausaha secara kontinu atau berkelanjutan, membuat aplikasi-aplikasi kewirausahaan, alur pelatihan kewirausahaan, dan ambil usaha-usaha yang spesifik, yang sangat diminati serta memang dikuasai secara menyeluruh. 
Pengembangan inovasi pelatihan kewirausahaan merupakan suatu proses panjang yang berlangsung dalam masyarakat, khususnya untuk anak berkebutuhan khusus. Inovasi adalah suatu usaha pembaharuan yang dilakukan oleh para inovator. Kemudian dipertegas oleh Rogers (1983), inovasi pendidikan mempunyai peranan penting dalam meningkatkan kualitas sumber daya manusia, karena berinovasi adalah mencari halhal yang bersifat mendapatkan keuntungan relatif, kompatibel, kompleksitas, trialabilitas dan dapat diamati. Dalam setiap proses pelatihan, ada suatu harapan untuk mengembangkan kualitas sumber daya manusia. Di sini ada suatu proses inovasi, karena akan ada daya upaya untuk peningkatan dan mencari gagasan-gagasan yang dianggap lebih baik.

Inovasi pelatihan kewirausahaan untuk kelompok anak berkebutuhan khusus seharusnya berjalan dengan mengikuti perkembangan dunia pelatihan kewirausahaan yang memang sangat maju akhir-akhir ini. Sumber daya manusia pelatihan kewirausahaan untuk kelompok anak berkebutuhan khusus adalah pokok utama yang dapat mengembangkan dunia pelatihan kewirausahaan di masyarakat. Pelatihan kewirausahaan untuk kelompok anak berkebutuhan khusus merupakan salah satu solusi dalam rangka mengembangkan sumber daya manusia kewirausahaan.

Efek langsung dari inovasi pelatihan kewirausahaan untuk kelompok anak berkebutuhan khusus yang berjalan dalam masyarakat, dapat mengubah pola pikir kelompok anak berkebutuhan khusus dari pola pikir pencari kerja ke pencipta lapangan kerja dengan jalan mengembangkan pelatihan kewirausahaan dan terjun kedunia kewirausahaan. Efek langsung inovasi pelatihan kewirausahaan untuk kelompok anak berkebutuhan khusus yang dapat terlihat dalam masyarakat memberikan nilai tambah terhadap pemerintah dan masyarakat - dapat memberdayakan kelompok anak berkebutuhan khusus yang ada di masyarakat menjadi kelompok calon pengusaha baru - dapat memberdayakan dunia pelatihan kewirausahaan untuk lebih maju secara profesional - terciptanya cara kerja antarfungsi yang lebih sederhana dan lebih mempermudah unit-unit terkait dalam mengembangkan pelatihan kewirausahaan -dapat melakukan peningkatan pelatihan kewirausahaan secara berkelanjutan dan berkembang secara terus menerus -dan semua kegiatan pelatihan kewirausahaan dapat dilakukan secara lebih murah dan cost effective.

Akselerasi inovasi pendidikan dan pelatihan dilakukan guna memacu ketertinggalan dalam rangka pelatihan kewirausahaan untuk menghadapi pasar lepas yang membutuhkan kelompok calon pengusaha baru profesional yang memang ulet dan tangguh dalam bersaing di dunia kewirausahaan yang sudah tidak berbatas lagi. Pengembangan pelatihan kewirausahaan secara lebih cepat dan berbobot lagi berkualitas sangat dibutuhkan oleh masyarakat. Karena, masa melenium ketiga ini semua kegiatan dilakukan secara lebih cepat dan tepat. Oleh karena itu, diperlukan sumber daya manusia yang benarbenar menguasai pengetahuan kewirausahaan dan pelatihan kewirausahaan untuk menghadapi tantangan-tantangan masa depan yang lebih rumit dan komplek.

Pelatihan kewirausahaan dan pengembangan sumber daya manusia dalam masyarakat perlu dilakukan dalam rangka pemberdayaan sumber daya manusia kewirausahaan, terutama untuk kelompok calon pengusaha baru. Pemanfaatan kelompok masyarakat untuk dididik dan dilatih dalam kewirausahaan adalah pemberdayaan masyarakat untuk dapat menciptakan lapanganlapangan kerja baru. Dan kelompok calon pengusaha baru akan dapat meningkatkan pertumbuhan ekonomi dalam masyarakat. Karena semua aktivitas kelompok calon pengusaha baru akan berhubungan langsung dengan uang dan pertumbuhan ekonomi secara langsung.

Pengembangan sumber daya manusia pengangguran menjadi kelompok calon pengusaha baru sebagai suatu proses berkelanjutan adalah suatu usaha dan upaya untuk mengembangkan masyarakat. Ini adalah salah satu aset yang dimiliki masyarakat yang tidak akan pernah habishabisnya dan bahkan akan bertambah banyak secara terus menerus.

Manusia modern saat ini diharuskan untuk berproduktivitas secara maksimal untuk memberikan sumbangan yang berarti pada lingkungan di sekitarnya. Siasia atau mubazir apabila produktivitas yang ada pada manusia 
tidak dimaksimalkan ketika yang bersangkutan hidup. Kehidupan merugi seharusnya dihentikan dan dikembangkan ke kehidupan yang bermanfaat serta menguntungkan bagi diri sendiri dan masyarakat lingkungan.

Pengembangan sumber daya manusia berkebutuhan khusus menjadi calon pengusaha baru di era pasar lepas merupakan suatu cara dan upaya agar meraka dapat mengembangkan dirinya secara spesifik dan general. Otonomi adalah suatu peluang emas bagi masyarakat daerah untuk mengembangkan dirinya dalam segala bidang secara kreatif dan inovatif. Demikian juga untuk pendidikan dan pelatihan bagi kelompok anak berkebutuhan khusus menjadi calon pengusaha baru untuk memasuki otonomi dan pasar lepas dalam rangka menghadapi masa depan yang penuh dengan persaingan dan tantangan.

Pengembangan pelatihan kewirausahaan sangat membantu pemerintah dan masyarakat untuk menciptakan kelompok pengusaha baru yang mampu mengembangkan masyarakatnya sendiri. Kebebasan yang dimiliki ini benar-benar digunakan untuk meningkatkan kualitas kelompok anak berkebutuhan khusus menjadi calon pengusaha baru untuk memperkuat dan mengembangkan potensi yang ada dalam masyarakat.

Perhitungan efektivitas pengembangan materi kewirausahaan anak berkebutuhan khusus didapat Ho: tidak ada perbedaan antara post-test dengan pre-test, $\mathrm{Ha}$ : ada perbedaan antara posttest dengan pre-test. Ho ditolak jika $\mathrm{t}$ hitung $>\mathrm{t}$ tabel, dan Ho diterima jika $\mathrm{t}$ hitung $<\mathrm{t}$ tabel. Dengan derajat kebebasan (df) $=19$, tingkat signifikansi $(\alpha)=0,05$ dan $\alpha / 2=0,025$ dan t tabel $(0,025: 19)=2,0930$. Dengan menggunakan program SPSS versi 12 didapat hasil perhitungan, t hitung $=47,540>2,0930$ maka Ho ditolak, berarti ada perbedaan yang signifikan antara post-test dengan pre-test. Nilai t hitung positif menunjukan nilai post-test lebih besar daripada pre-test. Jadi dapat disimpulkan, bahwa materi kewirausahaan efektif untuk memberdayakan anak berkebutuhan khusus untuk melahirkan calon-calon pengusaha baru dalam masyarakat, khususnya anak-anak unggul. Begitu juga dengan hasil perhitungan rata-rata pengembangan bentuk pelatihan yang datanya diambil bersamaan dengan penyelenggaran proses pelatihan kewirausahaan maka bentuk pelatihan yang diselenggarakan dalam masyarakat efektif untuk pengembangan anak berkebutuhan khusus, khususnya anak-anak unggul menjadi calon-calon pengusaha baru dalam masyarakat.

\section{Simpulan dan Saran}

\section{Simpulan}

Pengembangan rancangbangun pelatihan untuk kelompok anak berkebutuhan khusus menjadi calon pengusaha baru ada hal. Pertama membangun rancangbangun pelatihan untuk kelompok anak berkebutuhan khusus dalam masyarakat. Kedua, mengembangkan rancangbangun pelatihan untuk kelompok anak berkebutuhan khusus. Ketiga, meningkatkan sumber daya manusia pelatihan untuk kelompok anak berkebutuhan khusus di masyarakat. Keempat, melakukan pengorganisasian tim pelatihan untuk kelompok anak berkebutuhan khusus dan calon pengusaha baru dalam masyarakat. Kelima, menatakembangkan dan mengelola organisasi pelatihan untuk meningkatkan pelatihan kewirausahaan anak berkebutuhan khusus. Keenam, meningkatkan pelayanan kepada masyarakat untuk pelatihan anak berkebutuhan khusus, agar calon pengusaha baru dapat dilahirkan lebih banyak dan mampu berusaha sebagai pengusaha pemula dalam pasar lepas secara profesional.

Peningkatan bentuk pengembangan pelatihan untuk kelompok anak berkebutuhan khusus menjadi calon pengusaha baru dalam masyarakat adalah sebagai berikut: a) Mengikuti bentuk proses penyelenggaraan pelatihan untuk anak berkebutuhan khusus sesuai dengan tahapantahapan yang telah dibuat; b) Mengadakan pelatihan untuk anak berkebutuhan khusus sesuai dengan bentuk pelatihan yang sedang dikembang-kan secara berkala dan berkelanjutan; c) Menginformasikan bentuk pelatihan untuk berkebutuhan khusus yang sesuai dengan perkembangan; d) Mendiskusikan bentuk pelatihan untuk anak berkebutuhan khusus yang selalu berkembang sesuai dengan perkembangan dunia kewirausahaan; e) Pembuatan media dan alat bantu pelatihan untuk anak berkebutuhan khusus yang sesuai dengan bentuk pelatihan 
kewirausahaan yang sedang dikembangkan; f) Bentuk pelatihan dan proses pembelajaran pelatihan anak berkebutuhan khusus seharusnya saling dapat menyesuaikan untuk dapat diimplimentasikan pada anak berkebutuhan khusus.

Pengembangan materi kewirausahaan untuk anak berkebutuhan khusus menjadi calon pengusaha baru adalah sebagai berikut: a) Mengkaji materi kewirausahaan untuk anak berkebutuhan khusus yang sesuai dengan karakteristiknya dan calon pengusaha baru; b) Melaksanakan materi kewirausahaan anak berkebutuhan khusus untuk kelompok calon pengusaha baru dan melahirkan calon-calon pengusaha baru; c) Menempatkan kelompok calon pengusaha baru yang sudah menguasai dan pandai menjadi pengusaha pemula di dalam masyarakat; d) Mengembangkan materi kewirausahaan untuk anak berkebutuhan khusus secara terus menerus untuk menyesuaikan dengan perkembangan kemajuan dunia kewirausahaan secara profesional.

\section{Saran}

Pengembangan dan penciptaan rancangbangun pelatihan kewirausahaan anak berkebutuhan khusus untuk meningkatkan, mendorong, dan membuat bentuk pelatihan dan materi kewirausahaan. Pengembangan bentuk pelatihan dan materi kewirausahaan untuk anak berkebutuhan khusus menjadi calon pengusaha baru dalam masyarakat sangat efektif untuk meningkatkan kemampuannya dalam berwirausaha. Permasalahan ini merupakan masalah yang mendasar yang harus mendapatkan prioritas utama untuk diselesaikan dan dikembangkan sesegera mungkin, dalam rangka menurunkan angka pengangguran di masyarakat.

Otonomi daerah sebaiknya disikapi dengan lebih arif oleh masyarakat dalam rangka membenahi dirinya dengan mengembangkan pelatihan kewirausahaan untuk anak berkebutuhan khusus. Profesionalisme pemerintah dalam mengembangkan pelatihan kewirausahaan untuk anak berkebutuhan khusus dan kewirausahaan merupakan suatu kebijakan yang harus memihak pada kelompok anak berkebutuhan khusus.

Pemerintah perlu mengadakan pengkajian kualitas kinerja unit-unit kerja terkait untuk kemajuan pengembangan pelatihan kewirausahaan untuk anak berkebutuhan khusus di lapangan dan penyesuaiannya dengan kebijakankebijakan yang dikeluarkan pemerintah dan kemajuan ilmu pengetahuan dan teknologi serta seni dalam mengembangkan pelatihan kewirausahaan dan kewirausahaan itu sendiri.

Penciptaan rancangbangun pengembangan pelatihan kewirausahaan merupakan salah satu bentuk peluang untuk menjadikan anak berkebutuhan khusus menjadi calon pengusaha baru. Dengan cara membuat bentuk pelatihan dan materi kewirausahaan yang tepat dan efektif untuk anak berkebutuhan khusus menjadi calon pengusaha baru dalam masyarakat.

Penelitian ini merupakan penelitian dasar yang berpotensi untuk membangun dunia kepelatihan kewirausahaan untuk anak berkebutuhan khusus, karena masih luas dan dalamnya lapangan pelatihan kewirausahaan yang harus diarungi untuk meningkatkan profesionalisasi sumber daya manusia untuk profesi kewirausahaan. Oleh karena itu, penelitian lanjutan diperlukan untuk kewirausahaan untuk anak berkebutuhan khusus ke tingkat yang lebih tinggi, dalam mencapai tatanan profesionalisme yang didasarkan pada tatanan desentralisasi daerah.

Dalam rangka memberikan efektivitas hasil penelitian yang telah dilaksanakan, terhadap implementasinya untuk memberdayakan kelompok anak berkebutuhan khusus dalam masyarakat. Diperlukan dukungan dan komitmen yang konsisten dari semua elemen yang terkait. Dalam upaya memberikan kemampuan berwirausaha calon pengusaha baru di kalangan anakanak unggul, sehingga pengembangan pelatihan kewirausahaan kelompok anak berkebutuhan khusus dapat berhasil dengan baik. 


\section{Pustaka Acuan}

Bank Dunia, Jumlah orang Miskin di Indonesia, Metro TV: 02/01/2007.

Bungin. 2003. Metode Penelitian Naturalistik Kualitatif, PT Tarsito, Bandung.

Davies. 2005. The Art of Training and Development, The Training Manager's, a handbook, PT Gramedia, Jakarta.

Direktorat PLB, 2004. Identifikasi Anak Berkebutuhan Khusus dalam Pendidikan Inklusi, E mail Versi@2005/2006.

Direktorat PLB. 2004. Identifikasi Anak Berkebutuhan Khusus dalam Pendidikan Inklusi, E mail Versi@2005/2006.

Dorodjatun. 2004. Berkurangnya Persentase Angka Pengangguran di Indonesia, Kompas 24 Juni 2004.

Istijanto. 2005. Metode Penelitian di Bidang Sosial, Bayu Media dan UMM Press, Malang.

Kasmir. 2006. Kewirausahaan. Divisi Buku Perguruan Tinggi, PT Raja Grafindo Persada, Jakarta.

Kuncoro Jakti, Dorodjatun. 2004. Berkurangnya Persentase Angka Pengangguran di Indonesia, Kompas 24 Juni 2004.

Kuswara. 2005. Buku Pendidikan Luar Sekolah, Kewirausahaan, untuk Paket C, PT Indahjaya Adipratama, Bandung.

McMillan and Schumacher. 2001. Research in Education, A Conceptual Introduction, Longman, New York.

Mulyani, S. 2007. Pengangguran di Indonesia, Metro TV: 02/01/2007.

Rogers, EM. 1983. Diffusion of Innovation, The Free Press A Division od Macmillan Publ. Co. Inc. New York.

Suparno. 2008. Bahan Ajar Pendidikan Anak Berkebutuhan Khusus, Direktorat Dikti, Depdiknas, Jakarta.

Sugiyono. 2007. Metode Penelitian Pendidikan, Pendekatan Kuantitatif, Kualitatif, dan R \& D, Alfabeta Bandung.

Sugiyono. 2002. Manajemen Diklat, Penerbit Afabeta, Gerlong Hilir Bandung.

Suharto, E. 2006. Membangun Masyarakat Memberdayakan Rakyat, Rafika Aditama, Bandung.

Suryana. 2006. Kewirausahaan, Pedoman Praktis: Kiat dan Proses Menuju Sukses, Penerbit Salemba Empat, Jakarta.

Sukmadinata, NS. 2006. Metode Penelitian Pendidikan, Pascasarjan UPI dengan Remaja Rosdakarya, Bandung.

Zuriah. 2006. Metodologi Penelitian Sosial dan Pendidikan, Teori - Aplikasi, Bumi Aksara, Malang. 